report deals not only with accidents that have actually occurred but also with the large-scale methods for preventing danger and damage which have been discussed with the electrical industry. The total number of fatal accidents reported, 112, is satisfactorily small, and comparing it with previous years it indicates no marked variation from a steady mean. The variations in the numbers reflect the periods of industrial activity and depression. It is noted that there has been an increase in the number of accidents to male persons less than twenty-one years of age during the last five years. A feature of the electrical accidents is the large percentage ( 55 per cent) in which the injury was due to burns alone. Joining of metal by arc welding is rapidly becoming popular. Practically all the welding accidents (57) are cases of conjunctivitis (eye-flash) and none of them was fatal. Stress is very properly laid on the provision of suitable goggles for workers liable to be exposed to radiations from the ares.

\section{Vehicle Tests on Motor Roads}

HIGHWAY engineers are interested in tests recently made by the German road authorities on the comparative efficiencies of motor roads and ordinary roads. An abstract of a paper on the subject is given in Roads and Road Construction of August. The results of the driving efficiencies obtained in two approximately parallel roads joining Bruchsal to Bad Nauheim, a distance of about 91 miles, are given. One of these was an autobahn road and the other a State road specially constructed for long-distance journeys which had been greatly improved during the last four years. The latter road was comparable in layout and surface condition with a Class I road in Great Britain. The tests were made with an ordinary high-powered car. On the State road, the journey took $2 \frac{1}{4}$ hours at an average speed of 44 miles per hour. On the motor road it took $1 \frac{1}{4}$ hours at an average speed of 74 m.p.h.; on the State road the average speed was only 56 per cent of the maximum speed of the car; on the motor road it was 92 per cent. On a second journey undertaken on the motor road at the same average speed as that attained on the ordinary road, the petrol consumption dropped from $5 \cdot 5$ to $3 \cdot 1$ gallons. Considering that on the ordinary road 351 ears were met and 158 overtaken, exclusive of bicycles and pedestrians, the feeling of safety is much greater on the motor road as there are no oncoming cars to avoid. The tests were made with a 3.21 Mercedes car. It is concluded that on the motor road you always arrive quicker at your destination than is possible on the ordinary road and consume less fuel. On this road also the safety is greater and the stress to which the driver and car are subjected is much less. Further experimental results are to be carried out on speed trials with other cars.

\section{Kelvin and the Atomic Theory}

Is his tribute to Lord Rutherford in Nature of October 6, Prof. A. S. Eve states that Lord Kelvin died in unbelief of Rutherford's atomic theory. Mr. C. Turnbull, 21 Percy Park, Tynemouth, North- umberland, has pointed out that this is incorrect. In his presidential address to the Physical Society (January 1936), Lord Rayleigh (p. 22I) states that Kelvin argued emphatically with Rutherford and himself against the atomic origin of the energy. Rayleigh asked him to make a bet of five shillings that within three (or six) months he would admit that Rutherford was right. Within the allotted period Kelvin came round, and at the British Association he made a public pronouncement in favour of the internal origin of the energy of radium. He also produced the five shillings in settlement of the bet.

\section{Announcements}

THE Right Hon. Lord Riverdale has been appointed chairman of the Advisory Council to the Committee of the Privy Council for Scientific and Industrial Research in succession to the late the Right Hon. Lord Rutherford of Nelson. Sir William H. Bragg has been appointed a member of the Advisory Council.

THe following have been elected as officers of the Cambridge Philosophical Society for 1937-38: President: Sir F. Gowland Hopkins. Vice-Presidents : Dr. C. G. Darwin, Mr. F. P. White, Prof. J. Gray. Treasurer: Dr. J. D. Cockcroft. Secretaries: Mr. A. H. Wilson, Dr. O. M. B. Bulman, Mr. J. A. Ratcliffe. New Members of the Council: Dr. N. Feather, Dr. C. F. A. Pantin, Mr. E. N. Willmer.

AT the anniversary meeting of the Mineralogical Society held on November 4, the following officers were elected : President: Dr. L. J. Spencer; VicePresidents: Prof. P. G. H. Boswell and Prof. C. E. Tilley; Treasurer: Mr. F. N. Asheroft; General Secretary: Lieut.-Colonel W. Campbell Smith ; Foreign Secretary: Prof. A. Hutchinson; Editor of the Journal, Dr. L. J. Spencer.

AT 6.57 p.m. (G.M.T.) on November 16, Flying Officer Clouston and Mrs. Kirby-Green arrived at Capetown from London, having flown the distance in 45 hours 2 minutes. The route taken was through Cairo, Khartoum, Broken Hill and Johannesburg. They have thus beaten the record set up by Miss Amy Johnson by 33 hours 23 minutes.

Fon the first time in history, a medical man in the person of Dr. Roussy, dean of the Paris medical faculty and well known for his researches on the nervous system, endocrinology and cancer, has been elected rector of the University of Paris.

The Francis B. Garvan Gold Medal established by the American Chemical Society to honour outstanding women chemists has been awarded to Dr. Emma R. Carr, head of the Mount Holyoke Department of Chemistry. Dr. E. Bright Wilson, jun., assistant professor at Harvard University, has received the one thousand dollar award from the Society for his experimental work in physical chemistry. 